\title{
Performance of BMU in Mangrove Protection: A Case of Mlingotini Village in Bagamoyo District \\ Dominiko Orangi Okoth*
}

Environmental Planning and Management, Misungwi District Council Mwanza, Mwanza Tanzania²Institute of Regional Science (IfR), Karlsruhe Institute of Technology (KIT), Karlsruhe, Germany

\begin{abstract}
This study was carried out to assess the performance of Beach Management Units (BMU) in mangrove protection in Bagamoyo district; A case of Mlingotini village in Zinga ward. The study anticipated to address the three specific objectives: To examine the strategies used by BMU towards mangrove protection at the study area, to examine the extent to which BMU has reduced mangrove destruction and to explore the challenges facing mangrove protection initiatives by BMUs. A total of 97 respondents were covered including 4 key informants. Findings from this study show that awareness on mangrove protection is still inadequate. Also the study established that, although BMU has reduced cutting of mangrove for various purposes, but there is still a significant destruction which needs to be addressed. The study established lack of environmental education, building materials, business activities, lack of working facilities, social ties, unemployment, lack of government support and week by-laws as major challenges facing mangrove protection by BMU. Following the findings it is recommended that BMU should device regular awareness programmes to build understanding to the whole community. Furthermore, BMUs should device strong by-laws geared towards mangrove protection so as to make people fear of to cut mangrove. Lastly, the government support is needed to provide working facilities, to create employment and fight illegal business of mangroves.
\end{abstract}

Keywords: Mangrove forest; BMU; Environmental protection;

General coastal environment

\section{Introduction}

Mangrove forests comprise only $0.12 \%$ of the world's total land area, but are highly productive ecosystems that underpin a major portion of the world's fisheries. In Tanzania mainland, Mangrove forest stretches from Tanga to Mtwara. They grow along the flats between coastal villages and the shore. In Bagamoyo, mangroves are distributed along the coastal section stretching from Ras Mbegani to Mlingotini village (Mbegani bay) where they occur as mangrove fringes with relatively denser thickets at Mbegani and Mlingotini. Outside the Bay, there are stands of mangroves at Kaole, and Kondo sheltered creeks and lagoons [1]. Also Mangrove forests function as irreplaceable feeding, shelter and nursery grounds for different ecologically and economically valuable aquatic organisms such fish, prawn, and crab species. The forests also secure the land, preventing shoreline erosion. Mangroves are also important for the health and water quality of near-shore ecosystems such as sea grass beds and coral reefs that develop best in clear waters.

The status of mangrove forest in Tanzania coastline is declining especially in beaches of Bagamoyo district. In some places the beach has receded considerably and protection from erosion has since decreased as a consequence of mangrove destruction [2]. People cut mangroves for fuel wood and charcoal production. Some of the fuel wood is consumed locally, but there is also a great demand from Zanzibar [3].

Mangrove resources have been protected in Tanzania ever since 1898 when the German administration established a mangrove management ordinance. The British subsequently expanded the mangrove reserves to cover 80,000 hectares on the mainland. After independence, the Tanzanian government continued to protect mangroves as territorial forest reserves.

However, the reserves were neither managed nor enforced. In 1987, the Director of Forestry imposed a national ban on the cutting of mangroves, pending the preparation of a mangrove management plan, which was approved in 1994 . Through this plan, all mangroves in
Tanzania are protected through a national zoning scheme.

Tanzania implemented a number of environmental protection initiatives such like BMUs which operate in fishing beaches and whose main functions are geared towards sustainable management, conservation and protection of marine and coastal resources in their locality. Since mangrove is closely connected to various coastal ecosystem functions including fisheries, BMUs should also play the major role in protection of mangrove [4]. The presence of BMUs in Bagamoyo district could be expected to improve the condition of mangrove forest, but in contrast the mangrove is still in a declining state in the Bagamoyo coastline including Mlingotini village (a new eco-village). Past studies do not show information on the strategies and performance of BMUs in protection of mangrove forests which is among coastal resources largely connected to fisheries and coastal ecosystem.

Then the purpose of this research was to assess the performance of Beach Management Units (BMU) in mangrove protection at Mlingotini village. The research question is "to what extent has the BMU reduced decline of mangrove at the study area?"

\section{Study location}

The study was conducted at Mlingotini eco-village (in Zinga ward) in Bagamoyo District. Mlingotini village was selected because it is

*Corresponding author: Dominiko Orangi Okoth, Bd. Environmental Planning and Management, Misungwi District Council Mwanza, Mwanza Tanzania, Tel: 255( 0)683394915/255(0)756292919; E-mail: dominicorang@yahoo.com

Received July 20 2015; Accepted July 27 2015; Published July 312015

Citation: Okoth DO (2015) Performance of BMU in Mangrove Protection: A Case of Mlingotini Village in Bagamoyo District. J Coast Zone Manag 18: 410. doi: 10.4172/2473-3350.1000410

Copyright: @ 2015 Okoth DO. This is an open-access article distributed under the terms of the Creative Commons Attribution License, which permits unrestricted use, distribution, and reproduction in any medium, provided the original author and source are credited 
located within Mbegani bay which is among areas that experience the extreme decline in mangrove forest. According to 2012 national census; the village has a total of 2,720 households [5].

\section{Methodology}

In accomplishing this work, non-experimental research design was used to obtain data. Both primary and secondary data were used. Primary data was collected through field interview of 97 representatives from the study area (including BMU officials). Secondary data was collected from different published sources. The literature review involved reviewing data from reports and articles. Most of literature review was done online by accessing different websites, researches, papers and articles. Secondary data sources used include BMU reports and records, fisheries management series and other web documents.

\section{Results and Discussion}

\section{Concepts and ecological importance of mangrove}

Mangroves are salt-tolerant forests or swamp ecosystems that occur along tropical and sub-tropical coastlines. Mangrove forests occur at the interface of land and sea along tropical and subtropical coastlines. They occur where there is abundant fine-grained sediment (silt and clay) in the upper part of the inter-tidal zone, usually in sheltered bays, lagoons, tidal creeks and inlets and around river mouths. Mangrove forest play a role of purifying the surface water before entering to the ocean, recycles nutrients and traps land-based debris, sediments, and suspended particulate matter carried to the coast by rivers, providing habitat for a range of species as well as nursery areas for the juvenile stages of commercially important fishery species, such as fish, shellfish, prawn, and crab species [6]. They are thus important for the health of near shore ecosystems like sea grass beds and coral reefs that develop best in clear waters. Approximately 35\% of mangrove area has been lost or converted by human activities [7].

\section{Concept and role of BMU}

Beach Management Units (BMUs) are the tools established by the government of Tanzania for the purpose of enforcement of the Fisheries Act, 2003 and Fisheries Regulations, 2005, Preparation of by-laws to facilitate the implementation of the National law, Ensuring beach sanitation and hygiene, collecting fisheries data/information, including fish catch, inspect fishing licenses, vessels, gear and fishing camps [8]. Also these units educate on the negative impact of illegal fishing practices and other environmental issues that affect fisheries resources and the general coastal environment [9]. The general coastal environment includes coastal and marine resources such as mangroves. The Fisheries Policy, 1997 provides guidance that promotes sustainable exploitation, utilization and marketing of fishery resources to provide food, income, employment, foreign exchange earnings, effective protection of aquatic flora and fauna, and environment to sustain development. It also gives a direction for change in attitude towards fisheries resource practices [10].

\section{Status of mangrove forests in Bagamoyo}

Overall in Tanzania, the mangrove resources seem to be relatively stable and in some places the mangrove cover is even expanding [2]. But in areas of Bagamoyo, uncontrolled cutting is still a problem. In some places the beach has receded considerably as a result of lost mangroves and protection from erosion has since decreased. People cut mangroves for fuel wood and charcoal production. Some of the fuel wood is consumed locally, but there is also a great demand from Zanzibar. A study by Francis and others on Development and Protection of the Coastal and Marine Environment in Sub-Saharan Africa revealed that while the economic importance of mangroves in Mbegani Bay is enormous, poorly controlled human activities through overexploitation of resources, and clear cutting of substantial areas of mangroves for firewood, charcoal making, solar salt pans, agriculture/ aquaculture, industries, urban and hotel developments are major factors that contribute to the degradation of mangroves in the Mbegani Bay area [11]. Tourism is taking its toll in mangrove degradation through clearing for hotel construction and opening of beaches, while illegal charcoal-making and salt-making also threaten the mangroves. Subsistence farming and private trading of mangrove poles, mostly illegal, are currently causing considerable damage and decline of mangrove forest in the Delta [3].

\section{Strategies used by BMU in protection of mangrove}

From the study results it has been identified that the strategies used by BMU to protect mangrove are education and public awareness, bee keeping, economic instruments (fines, charges, and use license), reforestation and permit system and laws and by-laws.

Education and public awareness: Education is the most important tool for developing human skills, knowing and liberating people [12]. Information from the study indicates that education and public awareness is among the main strategies used by BMU in mangrove protection. However, information shows that, only $5 \%$ of respondents have attended training. $74 \%$ are aware of the strategies through meeting while $21 \%$ are not aware. More efforts are needed to provide adequate education and public awareness on environmental protection [13].

Permit system, fines and charges: The study identified permit system as one of strategy used by BMU in protecting mangrove. Permit for utilization of mangrove is given by the village council office. As informed by key informant, the permitted uses of mangrove at Mlingotini village are boat repair (Taluma), building materials, cultivation of seaweed and firewood from dried branches of mangrove. However the permits incorporate some charges (Table 1).

For boat repair, a person can be allowed to obtain taluma of up to 20 or 30 pieces of mangrove by a charge of Tsh. 5,000 for 20 pieces and 15,000 for 30 pieces. Taluma refers to 20 or 30 pieces of mangrove tree used for boat repair to stabilize the boat. A korija of 20 pieces of mangrove tree for building materials is charged at Tsh. 5,000.

Korija refers to 20 pieces of mangrove tree used as building materials. The use permit for bee keeping and firewood is given free of charge. People are only allowed to collect dead (dried) branches of mangrove tree for firewood. However, the key informants explained that the procedures for charges and permit system are not successfully implemented due to weak law enforcement and social ties.

\begin{tabular}{|l|l|l|l|}
\hline Type of activity & Unit & Charges applied & Amount/un it (TSH) \\
\hline Boat repair & $\begin{array}{l}\text { Taluma (20 or } 30 \\
\text { pieces) }\end{array}$ & Use charges & 5000 or 1500 \\
\hline Firewood & Bundles & Use permit & No charge \\
\hline $\begin{array}{l}\text { Building } \\
\text { materials }\end{array}$ & Korija (20 pieces) & Use charges & 5,000 \\
\hline $\begin{array}{l}\text { Seaweed } \\
\text { farming }\end{array}$ & - & Use permit & No charge \\
\hline Beekeeping & - & Use permit & No charge \\
\hline Source: Mlingotini Village Executive's Office (2013) \\
\hline
\end{tabular}

Table 1: Permit and charges for use of mangrove. 
Laws and by-laws: The study revealed that, although BMU uses the laws guiding utilization of natural resources which includes Environmental Management act of 2004, (EMA, 2004), Fisheries Regulation of 2005 and Fisheries Act of 2003 and the District by-laws which strictly prohibit charcoal making from mangrove forest, the implementation of law enforcement is not successful.

Beekeeping: Beekeeping as also a strategy used by BMU to scare people of and reduce ecological footprint on mangrove. Beekeeping is mainly done by a group established by Mangrove Management Project (MMP) to perform mangrove protection. This project engaged in mangrove protection by funding and facilitating community groups. It faced out in 2012 but the group is still operating.

\section{The extent to which BMU has reduced mangrove destruction at the study area}

This part tries to explain the condition and state of mangrove forest at the study area before and after establishment of BMU. The variables studied were charcoal from mangrove, firewood from mangrove as well as the state of mangrove forest cover.

Rate of cutting mangrove: Poorly controlled human activities through overexploitation of resources, and clear cutting of substantial areas of mangroves for firewood, charcoal making, solar salt pans, agriculture/aquaculture, industries, urban and hotel developments are major factors that contribute to the degradation of mangroves [8].

Since establishment of BMU, there is reduction in cutting of mangroves for different purposes. The percentage of those who never cut mangroves for whatever purpose rose from $6.5 \%$ to $36.6 \%$.

Reduction in cutting mangrove for firewood: Figure 1 shows the rate of use of firewood from mangrove before and after BMU intervention. It indicates that proportion of those depend on mangrove for firewood has declined by $3.2 \%$ since the proportion of those who never use firewood from mangrove has increased from $48.4 \%$ before BMU intervention to $51.6 \%$ after BMU intervention with a change of difference of $3.2 \%$. However $48.4 \%$ still depends on mangrove for firewood (Figure 1).

Reduction in mangrove cutting for charcoal making: Figure

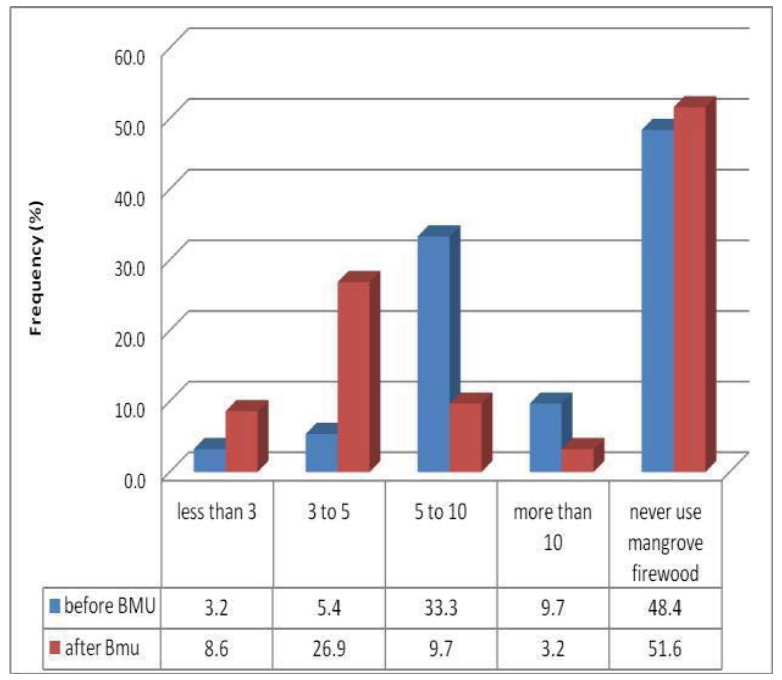

Figure 1: The rate of use of fire woods from mangrove.

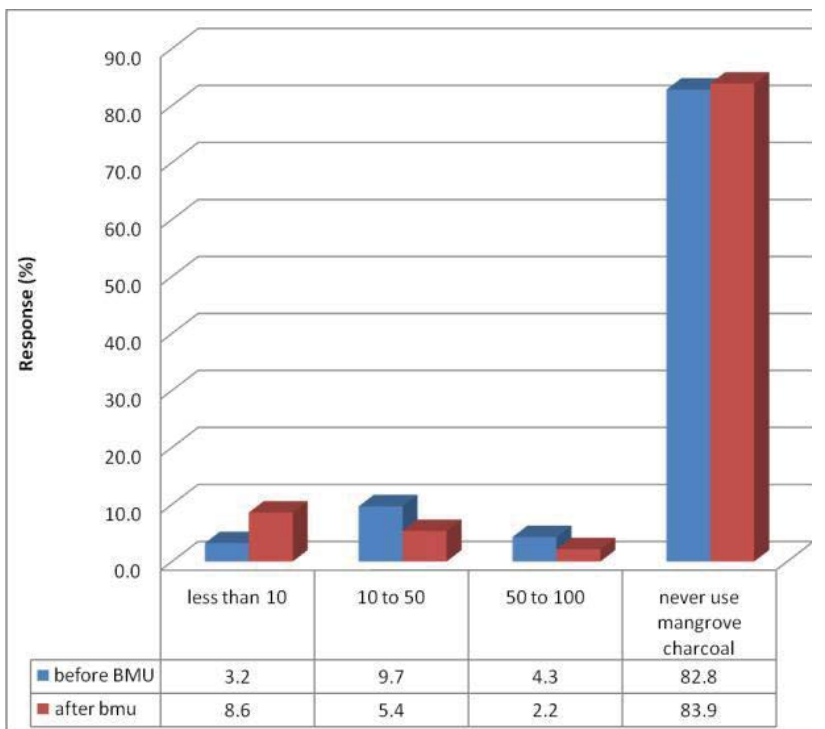

Figure 2: The rate of use of charcoal from mangrove.

2 shows the rate of use of mangrove charcoal before and after BMU intervention. It indicates that, dependence on mangrove for charcoal has increased from $82.8 \%$ before BMU intervention to $83.9 \%$ after BMU intervention (Figure 2).

In general, information in Figures 1 and 2 imply that BMU has increased mangrove protection through reduction of dependency on mangrove for charcoal and firewood. However having $48.4 \%$ dependents on mangrove for firewood is an indication that mangrove forest is still in destruction and more efforts are needed so as to further lessen the figure.

Mangrove forest cover: Data from the District forest office shows that mangrove forest covers the total area of $5051 \mathrm{Ha}$ for the whole district. There is no particular spatial data showing village area covered by mangrove, area cleared before and after BMU intervention as well as hectares reforested or number of mangrove trees replanted. This brings difficulty in measuring the increase or decrease in mangrove cover. Bagamoyo district has four protected areas (Exclussive/No take areas) which are Madunga, Mshingwi, Poyogo and mjini of which is neither permitted for fishing nor harvesting mangrove. However results from the respondents showed that mangrove forest condition is improving in a negligible rate since BMU intervention [14].

Mshingwi is under participatory management of Mlingotini in collaboration with Pande village in which BMU plays a major role in protection. The results show that, the status of mangrove forest is improving near the coast but in the far most where BMU cannot reach during patrol, the status is still declining because of lack of working facilities like boats for patrol, monitoring control and surveillance.

\section{Challenges facing mangrove protection initiatives by BMUs}

There are several challenges facing mangrove protection initiatives by BMU. The study identified lack of environmental education, building materials, business activities, lack of working facilities, social ties, unemployment, lack of government support and week by-laws's the major challenges. 
Because people lack employment and alternative means of income, they engage in cutting mangrove for various purposes. Others cut and sale mangrove as a source of income, others cut mangrove for building materials because they have limited financial capacity to purchase alternative building materials. This brings a challenge that if the use of mangrove is to be abolished, how will people run their lives?

Business activities (hotels, tourism and export of mangroves) are among the challenges facing mangrove protection by BMU. Large investors are being given permit by the government to clear mangrove forest to construct hotels and tourist sites. Not even BMUs or village environmental committees are able to stop them. Three tourist hotels were observed which is Bomani Bungalow just adjacent to landing site, Kasiki hotel bordering NFDC (FETA), and Lazy Lagoon in a small island (Mshingwi). Tourism has been identified as as among activities causing mangrove destruction through clearing of mangrove forest for hotel construction and opening of beaches. Furthermore it was found that mangroves are being cut and exported to Zanzibar for sale without even consulting the BMU or responsible village authority [15].

Social ties also have been identified as a challenge in mangrove protection. Being a part of the society, BMU committee members fail to enforce the law fearing to of creating bad social relationship with other members of the society.

Other challenges established are lack of working facility (motorized boat) and protective equipment (P.P.E) such as gloves, buoyancy aids and, Lack of government support, Weak by-laws and Lack of environmental education which must be addressed to ensure adequate protection of mangroves.

\section{Conclussion and Recommendations}

The main objective of this study was to assess the performance of Beach Management Units (BMU) in mangrove protection in Bagamoyo district (Mlingotini Eco-Village). The study has revealed a proportion of the society still has no adequate awareness on mangrove protection. Only small proportion of the society showed to have attended training. The study has also established that BMU contributed in reducing mangrove destruction by reducing cutting for different uses. However the performance is unpromising because some proportion of population still cut mangroves as a means of getting income, fuel wood, building materials and materials for boat repair [16,17]. Thus, more efforts are needed to further reduce the ecological footprint on mangrove. Lastly, the study established several challenges facing mangrove protection by BMU. Such challenges as social ties, persistent unemployment, business activities, Lack of working facilities, weak by-laws, social ties and unemployment and building materials if not solved, the protection of mangrove by BMU will still be a puzzle. The study discovered that many people in the study area have low education level (primary education) including BMU executive committee (BMU EC), thus limit their capacity towards effective implementation of mangrove protection and conservation of the general coastal environment.

BMU Executives in collaboration with village government under guidance of District council should schedule a periodic public education and regular awareness campaigns through meetings and traditional folk media to build awareness for participatory mangrove protection. In order to further reduce mangrove destruction, BMU in collaboration with village government and district council should device strong bylaws geared towards mangrove protection so as to make people fear of to cut mangrove. In line with public education, BMU Executives should be committed in enforcing the law effectively. The District council should plan for regular capacity build to BMUs to give them confidence to overcome the problems of social ties. The government through Tanzania Investment Centre (TIC) should enhance rural investment so as to overcome the problem of unemployment, illegal business of mangrove and to enable people afford alternative building materials. Government should support BMU with motorized boats and surveillance equipment for patrol as well as buoyancy devices [18].

\section{References}

1. Tobey J, Robadue D, Shaghude YW, Muhando C, Kalangahe B, et al. (2013) State of Mbegani Bay: The Ecosystem, Livelihoods, and Future Status, Tanzania. Coastal Resources Center, Graduate School of Oceanography, University of Rhode Island, Narragansett, RI: 49

2. Wang Y, Ngusaru A, Tobey J, Makota J, Bonynge G, et al. (2003) Remote sensing of mangrove change along the Tanzania coast. Marine Geodesy: 26.

3. Torell E, Mmochi A, Spierling P (2006) Bagamoyo Governance Baseline: Coastal Resources Center. University of Rhode Island: 24.

4. URT (2009) Guidelines for establishing Community based collaborative Fisheries management in marine Waters of Tanzania.

5. National Bureau of Statistics-NBS (2013) National census 2012.

6. Lugendo B, Nagelkerken R, Kruitwagen G, Van der Velde G, Mgaya YD (2007) The relative importance of mangroves as feeding habitat for juvenile fishes: a comparison on mangrove habitats with different settings. Bulletin of Marine Science 80: 497-512

7. Giesen W, Baltzer M, Baruadi R (1991) Integrating Protection with LandUse Development in Wetlands of South Sulawesi. Asian Wetland Bureau, Bogor (Indonesia).

8. Mukasa E (2005) Lake Victoria Resource User Groups Survey, Fisheries Management Series, Lake Victoria Fisheries Organization \& IUCN, Nairobi Kenya: 3.

9. URT (2010) Report on the Training of BMU's on Catch Assessment for 14 Coastal Districts, Ministry of Livestock Development and Fisheries, Fisheries Division.

10. URT (2003) The Fisheries Act No. 22 of 2003: Ministry of natural resource and Tourism-MNRT.

11. Francis J, Wagner GM, Mvungi A, Ngwale J, Salema R (2002) Development and Protection of the Coastal and Marine Environment in Sub-Saharan AfricaTanzania National Report, Phase 1: Integrated Problem Analysis. Dar es Salaam, Global Environment Facility.

12. URT (1999) National Fisheries Sector Policy, Ministry of Natural Resources and Tourism.

13. URT (1997) National Environmental Policy, Vice President's Office, Dar es Salaam.

14. Sobo FS (1999) Fisheries Management in Tanzania. Proceedings of the Workshop on the Coastal Resources of Bagamoyo District, Tanzania. University of Dar es Salaam: 105-110.

15. URT (1998) National Forest Policy, Ministry of Natural Resources and Tourism

16. URT (2003) Integration of population variables in Development Planning, Part Two, planning commission, Dar es Salaam.

17. Winters P, Davis B, Corral L (2002) Assets, Activities and Income Generation in Rural Mexico: factoring in social and public capital. Agricultural Economic 27: 139-156.

18. Ngusaru AS, Tobey J, Luhikula G (2001) Tanzania State of the Coast 2001 People and the Environment, Tanzania Coastal Management PartnershipTCMP, Science and Technical Working Group, Dar es Salaam. 